\title{
FORMATION TYPES OF KOREAN NEOLOGISMS
}

\author{
Mahbuba Kudrat Qizi Allamova
}

1st Year Master Student, Tashkent State University Of Oriental Studies Supervisor: Phd. Yunusova G.D., Uzbekistan

\section{ABSTRACT}

This article analyzes the formation types of recent Korean neologisms used among youth. To this end, we use the data appearing in recent newspapers and online dictionaries showing the most recent usages. During the discussion, we categorize the data into several groups and show the types with examples. We also show that the types of acronyms were studied by Korean language professors. Finally, we conclude the article by claiming that the main characters in recent neologisms can be defined as a new bilingualism as the youngsters occasionally code-switch between standard usages and neologisms. This new trend is popular among teenagers and adult.

KEYWORDS: - Neologism, syllable, linguistics, acronym, consonantal acronym, attributive words, Noam Chomsky, abbreviation.

\section{INTRODUCTION}

The 21st century is the age of high information technologies. If we look at the world, from year to year there are changes in various fields, science and especially in the field of technology. As a result of such changes, there will be news in the language as well. Because new words are needed to explain and define new events and things. It is known that the vocabulary of a language is constantly updated with new units. Therefore, there are cases when new words appear in the language. Such words are called neologisms in linguistics. But over time, certain words, called neologisms, will inevitably lose their novelty once they are fully mastered from a linguistic point of view. In this case we will be able to exclude them from the list of neologisms.

Noam Chomsky, American professor known as the "father of modern linguistics," says about language: "Language is a process of free creation; its laws and principles are strict, but the methods of applying them are free and infinitely diverse. Even the interpretation and use of words involves the process of free creation 1 ."

Neologisms ( / ni:'pledzızam / ; Greek neo- "new" and logos - "word") are words or phrases that appear in the language as a result of various needs ${ }^{2}$.

\footnotetext{
${ }^{1}$ Naom Chomsky "Language and Freedom" lecture. University of Chicago, 1970

${ }^{2}$ A.Madaliyev. Annotated dictionary of the Uzbek
} 
CURRENT RESEARCH JOURNAL OF PHILOLOGICAL SCIENCES 2(12):

90-94, December 2021

DOI: https://doi.org/10.37547/philological-crjps-02-12-19

ISSN 2767-3758

(C2021 Master Journals

Crossref do

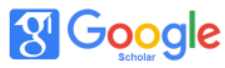

Accepted14th December, 2021 \& Published 19th December, 2021

Indeed, as McDonald, LJ puts it, "Neologisms are often associated with changes in culture and technology" 3 .

Neologisms can occur for several reasons and can vary in different languages. For example, neologisms can be constructed from words learned from a foreign language, or word formation from an already existing lexicon can also be observed.

Neologisms in Korean language appear in the following ways:

1) It can be made through words learned from a foreign language. For example,

버스 (bus), 택시 (taxi), 슈퍼마켓 (supermarket), 커피숍 (coffee shop), 버터 (butter), 스포츠 (sport), 골프 (golf).

2) Acronym in which the initial syllable of each word group is picked up. For example: 쌩 얼 (face without make-up), 남친 (boyfriend), 여친 (girlfriend), 안궁 (not interesting), 비추(don't recommend), 생축 (happy birthday).

Analyzing and studying the general structure of Korean neologisms is not as easy as memorizing vocabulary which is available in the language. New words constantly emerge from the daily communication of young people. Also, depending on the length of the time period, word formation through the addition of syllables can vary. Taking into account exactly these factors of neologisms samples of Korean neologisms used in SNS (social network) text messages have been selected by Jungang Ilbo ( 중앙일보4 ). This study analyzes

language. - Tashkent: State Scientific Publishing House, 2006. Volume 3. - B.34

3 McDonald, LJ The meaning of neologisms as cultural and technical symbols. - England, 2005.

${ }^{4}$ Korean popular journal. how newly emerging words reflect current trends in language use among the younger generation.

From the past years the interest of Korean neologisms has been increasing. Particularly, the neologisms that have started to be used among young people on the Naver Band website and was published in the most popular journal Joongang Ilbo.

The most common neologisms these days among the young population include:

마상 (heart pain), 버카층 (transport card), 버정 (bus station), 남사친 (boyfriend not lover), 여사친 (girlfriend not lover), 안물 (not asking).

The above neologisms are difficult to understand not only in the older generation but also people over 30 years. Many of them are acronyms in which only the initial syllable is picked up from each word block.

\section{Acronyms}

The most common type of neologism in Korean is an acronym used from the main syllable of these words. An acronym is a pronounceable word formed from the first letter (or first few letters) of each word in a phrase or title. The newly combined letters create a new word that becomes a part of everyday language. Using shortened forms of words or phrases can speed up communication ${ }^{5}$.

For example,

$$
\text { 단톡 - 단체 대화 (group conversation) }
$$

This neologism is an abbreviation formed from the main syllables of the words 단체 (tanche) group, 대화 (texva) - dialogue, 톡 (tok) - chat. 16학번 애동과 학생들이면 단톡에 들어가야하나요 ${ }^{6}$

Translation: Should I join a group chat if I am a 16th

5https://examples.yourdictionary.com/

6 https://kin.naver.com/qna/ 
CURRENT RESEARCH JOURNAL OF PHILOLOGICAL SCIENCES 2(12):

90-94, December 2021

DOI: https://doi.org/10.37547/philological-crjps-02-12-19

ISSN 2767-3758

(C2021 Master Journals

Crossref doi) 81 Google

Accepted14 ${ }^{\text {th }}$ December, 2021 \& Published 19th December, 2021

grader?

A person who does not know neologism misinterprets these sentences.

Let's look at another example:

자삭 - 자신 삭제 (self-removal)

Analyzing this neologism, the word자삭 (chasak) is derived from the words 자신 (chashin) - itself, 삭제 (sakche) - deletion.

그는 글을 올린 며칠 뒤 자삭을 했다.

Translation: He deleted the ad which he had posted a few days later.

취존 - 취향 존중 (respect for the taste of others)

The word is now widely used among young people and is a combination of the words 취 -취향 (to like, to be inclined), 존 - 존중 (to respect, esteem). We can learn this word from the following example.

왜 민초단들은 취존하라면서 반민초단 취향존중 안해줄까요?

Translation: Why don't you take into account the opinion of the anti-minority group?

비번 - 비밀 번호 (secret number)

This neologism part of the 비 (pi) - 비밀 (pimil) "secret" and 번 (bon) - 번호 (ponho) is formed by the words "number". This neologism means the secret number of a safe or the secret number of an item.

마상 - 마음의 상처 (wounded heart)

The word 마 (ma) - 마음 (maim) is composed of the words "heart, soul" and 상 (sang) - 상처 (sangcho) means "wounded" and means "wounded heart" 7 . We can see this word through the following sentence.

마상이 힘들죠. 세상 모든 사람은 감정이 있다면 상처를 받습니다. 몸의 상처는 형태가 있어서 치료법이 있다면 바로 고칠 수 있지만 마음의 상처는 정해진 치료법이 아무것도

${ }^{7}$ namu.wiki
없어서 더 까다롭고 힘들죠8.

It's hard to be heartbroken. Everyone in the world is hurt if they have feelings. Wounds on the body have a shape and can be repaired immediately if there is a treatment, but wounds on the soul are more difficult and difficult because there is no set treatment.

최애 - 최고 애(愛, 사랑) best lover

This neologism consists of 최-최고 (chxvego) "excellent" and 애-애인 (ein) "lover". This neologism is widely used among young people in the KakaoTalk program. For example, 최애는 내가 정하는게 아니다. 최애가 갑자기 와서 심장을 때리며 “오늘부터 내가 니 최애다."라고 말하는 것이다.

The best lover is not my choice. The best lover suddenly comes and beats the heart and says, "From today on, I am your favorite."

Not everyone can understand when reading this part of the text. To do this, people must be aware of modern life or try to chatting with youth.

Furthermore, only English words can be used to make a "Korean" acronym.

For example,

$$
\text { 플랙스 - FLAX }
$$

The word Flex, derived from American hip-hop culture, is used as a bragging term for "wealth or valuables," and was used in 1992 by rapper Ice Cube in the song "Down for whatever" 9. 스샷 - 스크린샷 Screenshot

The fact that this neologism is not only used by Koreans but also people of the other countries and it is easy to understand.

If we look at the following neologism, it means "close friend" in English. But there is an alternative version of this neologism in Korean. "치난 친구 " (chinan chingu) is a close friend. Now let's look at the English version.

8 https://kin.naver.com

$9 \mathrm{https}$ ://namu.wiki/w/FLEX 
CURRENT RESEARCH JOURNAL OF PHILOLOGICAL SCIENCES 2(12):

90-94, December 2021

DOI: https://doi.org/10.37547/philological-crjps-02-12-19

ISSN 2767-3758

(C)2021 Master Journals

Crossref doi) 81 Google

Accepted14 ${ }^{\text {th }}$ December, 2021 \& Published 19th December, 2021

베프 - 베스트 프렌드 Close friend

In English, 베 - 베스트(best) best, and 프 프렌드(pirendi) friend.

\section{A neologism formed by the contraction of consonant letters. (Consonantal acronyms)}

Many large and well-known organizations and companies have very long names which are commonly abbreviated to a set of initials written in capital letters, usually with no full stops. Here are a few familiar examples ${ }^{10}$ :

BBC- British Broadcasting Corporation

ICI - Imperial Chemical Industries

FBI - Federal Bureau of Investigation

RSPCA - Royal Society for the Prevention of Cruelty to Animals

NATO - North Atlantic Treaty Organization

MIT - Massachusetts Institute of Technology

TUC - Trades Union Congress

Just like in other many languages like English, Korean youngsters formulate many acronyms which consist of (orthographic) consonants only as shown in the following examples ${ }^{11}$.

$\neg \curlywedge$

We do not know whether these letters have any meaning at a glance, but if we form a word by considering it as the capital letters of the syllable, the word is formed as follows: $\neg$ - 감, 스 - 사 "감사"(kamsa) means "thank you, thanks".

10 Sang-Cheol Ahn, Kyunney Egorova. MorphoPhonological Patterns of Recent Korean

Neologisms. - Russia: Advances in Social Science, Education and Humanities Research, vol 531, 2021.-P. 65

${ }^{11}$ Sang-Cheol Ahn, Kyunney Egorova. MorphoPhonological Patterns of Recent Korean

Neologisms. - Russia: Advances in Social Science, Education and Humanities Research, vol 531, 2021.-P. 65
大人

This neologism consists of $ᄌ$-죄 and $ᄉ$ - 송 “죄송”(chvesong) means "sorry".

大 $=$

If we anylise it, 大-축, ᄏ-하 “축하”(chukha) translation is "congratulations". However, even if 하 is written, sounds like "카" in oral speech and the letters $大 ~ \exists$ are used on social media.

ᄀ 大

If we analyze this neologism, the first letter of the syllables of the word 괜찮다 (kvechanda) is ㄱ괜(kven), 大- 찮다(chanda) which translates as "everything is okay".

$\neg$ 드기다려 Wait

The consonantal acronym can be made of English words. For example,

ᄂ ᄂ - 노노 (no no - from English) no

$\neg ㄱ$ - 고고 (go go - from English) forward

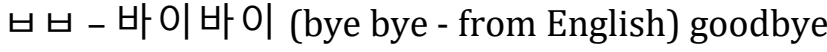

○ $\exists$ - okay - good

The initial sound of each example is in fact a vowel, but the Korean writing system requires the initial position of syllable should be filled with a consonant orthographically including the zero consonant "o" 12 . For example,

○ $\mathrm{O}$ - 응 "yes" to confirm

$\circ \sqsubset-$ 어디 ? where are you?

ㅇㄱㄹ 으이거레알 ? really?

Here we can see another examples.

ᄀ ᄂ $ᄌ$ - 가는중 I'm on my way

블 - 별로 not much

므-맞아 right

to $\mathrm{O}$ - 하이 $\mathrm{Hi}$

ㄹㄷ - 레디 ready

${ }^{12}$ Sang-Cheol Ahn, Kyunney Egorova. MorphoPhonological Patterns of Recent Korean

Neologisms. - Russia: Advances in Social Science, Education and Humanities Research, vol 531, 2021.-P. 65 
CURRENT RESEARCH JOURNAL OF PHILOLOGICAL SCIENCES 2(12):

90-94, December 2021

DOI: https://doi.org/10.37547/philological-crjps-02-12-19

ISSN 2767-3758

(C)2021 Master Journals

crossref do) :810 Google

Accepted14 ${ }^{\text {th }}$ December, 2021 \& Published 19th December, 2021

ᄃㄹ 그르림 hearing

믈 - 몰라 I don't know

The number of abbreviated words in this case is increasing in modern times.

\section{Conclusion}

In summary, we have discussed new words in Korean language by searching recent messages from SNS. Firstly, we introduce how neologisms can occur and give some examples. Secondly, the data are divided into several groups, detected the most commonly used type for neologism. Then by making a statistical distribution of the main types of new words, we proved that abbreviations predominate among young people. The main trend of neologisms can be described as a new bilingualism, as young people sometimes prefer to use neologisms over a standard mother language. This new trend is mainly driven by the younger generation, schoolchildren and teenagers.

\section{REFERENCES}

1. Sang-Cheol Ahn, Kyunney Egorova. Morphing Phonological Patterns of Recent Korean neologismo. - Russia: Advances in Social Science, Education and Humanities Research, vol 531, 2021.

2. Sbornik nauchnyx statey po koreevedeniyu studentov vuzov SNG Tsentr Koreevedeniya. - Kazakhstan, 2017.

3. McDonald, LJ (2005). E-: The meaning of neologisms as cultural and technical symbols.

4. Madaliyev A. Annotated dictionary of the Uzbek language. - Tashkent: State Scientific Publishing House, 2006. Volume 3.

5. Naom Chomsky "Language and Freedom" lecture. - University of Chicago, 1970.

6. International Journal of Korean Humanities and Social Sciences vol. 2/2016 P-128.
7. Jungang Daily Newspaper. South Korea, February 8, 2017.

8. https://kin.naver.com/qna/

9. namu.wiki

10. https://muegn.ru/uz/enciklopediya

11. https://namu.wiki/w/FLEX

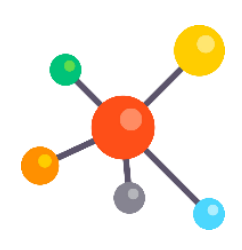

